\title{
Multilayered Appropriation(s)
}

\section{Josse Bade's Edition of Cicero's Philippicae tribus commentariis illustratae}

Early modern commentaries are an excellent genre for analysing the legacy of the classical texts. They appropriate an authoritative text, commend it to their readers' attention and negotiate its importance for the contemporary audience. At the same time, they are not just concerned with the text to be commented on. In order to contextualize it, they are heavily indebted to the classical tradition surrounding it. Thus, they can offer us insight into the way in which they approached classical culture in general and how they positioned the author at hand within this overall literary, political and cultural picture.

This chapter will concentrate on an edition of the last speeches by Cicero, the Philippics. It was printed in Paris in 1529 by Josse Bade and contained the commentaries of three Italian humanists: one attributed to (but according to modern views most probably not written by ${ }^{1}$ the Byzantine scholar and specialist on rhetoric George of Trebizond (1395-1472), another one by the Perugian professor of rhetoric Francesco Maturanzio (ca. 1443-1518), ${ }^{2}$ and a third by the famous humanist and teacher Filippo Beroaldo the Elder (1453-1505). ${ }^{3}$ After briefly introducing the genre of early modern commentary and the specific edition, I will touch upon the Philippics as Cicero's final oratorical words, then deal with what I term 'intertextual' interactions between the commentaries by Maturanzio and Beroaldo, and finally turn to Bade's prefatory letter and the question of why he might have published his edition in 1529. For limits of space, I will concentrate primarily on the paratexts of the edition and the three commentaries: Bade's preface and the introductions to the speeches by the individual commentators.

1 Cf. Classen 1993, 82 [=2003, 147-148]. According to Classen's analysis, the annotations attributed to George differ vastly both in length and complexity from the genuine rhetorical works and commentaries by George of Trebizond. The commentary to the Philippics by Pseudo-Trapezuntius gives "the impression [...] of someone trying to introduce Greek pupils to Cicero's speeches on a fairly elementary level”, whereas the 'real' George of Trebizond advocated a philosophical rhetoric, i.e., one that was no mere container of stylistic tricks, cf. Monfasani 1976, 294-299.

2 See Falzone 2009 for a biographical sketch of this slightly less known humanist.

3 The best brief introduction is Maréchaux 1997.

Ә OpenAccess. (C) 2020 Christoph Pieper, published by De Gruyter. (cc) BY-NC-ND This work is licensed under the Creative Commons Attribution-NonCommercial-NoDerivatives 4.0 License. 


\section{Josse Bade's 1529 edition of the Philippics}

Early modern commentaries were not only meant to introduce contemporary readers to the works and life of the ancient authorities. At the same time their purpose was to provide useful guidance for their readers' personal future, thus combining philological, historical, antiquarian or philosophical insights with contemporary interests. As Karl Enenkel and Henk Nellen in their very thorough introduction on early modern commentaries argue,

it was not a foregone conclusion that commentaries necessarily ought to play an auxiliary role. Commentaries were mainly studied-in various intellectual settings, to be sure-in order to acquire knowledge and skills. A 'pure' understanding of the source text was not the exclusive goal. ${ }^{4}$

In other words, most commentaries were means of appropriation rather than works of purely academic reception; they were meant to be relevant for the contemporary reader's life. Their aim could be to improve grammatical or rhetorical ability, but also to increase insight into contemporary political and philosophical discourses or to provide profound religious education. A second point worth mentioning is that commentaries in early modern times were a very open genre. Not only could they vary considerably in their approach to texts (from short glosses and lexical variants in school commentaries to encyclopaedic lemmas in thick and expensive books), commentators were also free to include anything they found useful from existing commentaries and/or other authoritative literature in their own explanations. Thus, in commentaries appropriation of an authoritative text happens through re-use and re-shaping of information available in other sources, including previous commentaries on the same text. This recurrent re-use of previous material could put the authorial identity of the commentator at stake, as his work was prone to being abbreviated, changed or simply 'borrowed' by later scholars. Such a relative openness of the genre adduced commentators, especially since the invention of the printing press, to establish their own authority as intellectuals, with the commentary as a potential medium to negotiate questions of "power and authority". 5

Josse Bade is one of those Renaissance intellectuals for whom negotiation of authority was of crucial importance. In his own self-representation he tried to

4 Enenkel/Nellen 2013, 3.

5 Cf. White 2013, 68-69 with further bibliographical references. See also Enenkel 2015, esp. $1-53$, on the importance of authorial self-fashioning in printed book within early modern intellectual culture. 
combine the image of a man of letters (who was offering material to others in a markedly unselfish manner) with the business of a professional printer who had to live off his job and therefore had to advertize his name in an adequate manner. ${ }^{6}$ The huge number of commentaries he published-partly with his own notes, ${ }^{7}$ partly with the annotations of others-attests to the success of his negotiation. Paul White even calls Bade "the exemplary figure of the early age of print". ${ }^{8}$ His 1529 edition Philippicae M. Tullii Ciceronis diligentissime ad exemplar fidelius repositae: \& tribus commentariis, Maturantii, Philippi Beroaldi, Georgii Trapezuntii, \& scholiis Ascensii, \& tabella literaria diligenter e commentariis emendatis collecta, illustratae is an interesting case in which the appropriation of Cicero's Philippics can be observed on several levels. First, Bade's decision to publish the Philippics with a foreword of his own anchors the edition in his own time and context. Second, he conserves and ennobles the three preceding commentaries. By reprinting them, he increases their canonical status, and by reprinting them together, he invites the reader to consider their interplay. Third, the three commentators themselves also relied on even earlier-ancient and early modern-material.

In the case of the Philippics, Bade's own input as a commentator, apart from the important prefatory letter, is marginal (he only adds some philological lemmas about alternative readings of the text-his main achievement, so he claims, is the thorough emendation of the text). The edition is an emended reprint of a previous Parisian edition from 1514, ${ }^{9}$ which also contained the same three commentaries. Maturanzio's enarrationes were first printed in 1488 in Vicenza by Enrico di Ca' Zeno (Henricus de Sancto Ursio); later they formed a fixed pair with Beroaldo's commentary ever since the latter's editio princeps had appeared in

6 For his self-portrayal see now White 2013, esp. 34-60 (ch. 2: "Self-representation and authorship"). White especially underlines (p. 36) that Bade in his paratexts, in contrast to Erasmus and other contemporaries, tends "in the [...] direction of self-abnegation and dissavowal of ownership", i.e., that Bade never sees himself as first author of his books; at the same time, he emphasizes "the intellectual labour he had invested in the text" (p. 50). It was not always easy for Bade to gain acceptance for his efforts from the other humanists, as shown convincingly by Diu 1997 .

7 His own commentaries were often labelled familiares commentarii of moderate difficulty with a clearly didactic aim, aimed at "instilling in his pupils a profound love of the belles lettres", as Crab 2014, 154, has argued. On the edition of the Philippics not quite fitting into this category, see below.

8 White 2013, 275.

9 Cf. Classen 2003, 40. He refers to the edition published by Jean Petit, Parisiis 1514 (no. 61064 in Pettigrew/Walsby 2012, 402), but I was not able to see this edition myself. 
Bologna in 1501 with Benedict Hector; ${ }^{10}$ the adnotationes attributed to George of Trebizond (to which I will henceforth refer as Pseudo-Trapezuntius), however, had already been printed in Venice by Nicolas Jenson, probably in 1475, and were first added to the two by Maturanzio and Beroaldo in the afore-mentioned edition from 1514. However, it is interesting to see that Bade decided to re-publish it in 1529, a year in which the so-called 'Ciceronianus' debates had reached an initial peak after the publication of Erasmus' homonymous treatise. ${ }^{11}$ I will return to this towards the end of this chapter.

\section{The use of sources: negotiating Ciceronian excellence}

As mentioned above, the commentaries reprinted by Bade negotiate the previous Ciceronian tradition through their specific use of ancient and early modern sources. We do not possess ancient commentaries or scholia on the Philippics, nor did the humanists of the fifteenth century. ${ }^{12}$ They therefore had to go back to other material. For the afterlife of certain passages of the speeches they could recur to Quintilian, who loved the Philippics and quoted from them regularly. Almost all of Quintilian's references to the speeches are quoted in the lemmas of Beroaldo's and Maturanzio's commentaries. For a more general appraisal of the text, early imperial declamation as preserved by Seneca the Elder (mostly in his sixth and seventh Suasoriae), but also Juvenal's tenth satire offered valuable material. For the historical background, it goes without saying that Cicero's own works were used. Valerius Maximus offers some details of Cicero's death, but it is especially the corpus of Plutarch's Lives-extremely successful in fifteenth-century Italy ${ }^{13}$ -

10 The edition M. Tullii Cic[eronis] Orationes per Philippum Beroaldum recognitae ac diligenter correctae (Bononiis: Hector, 1499) does not contain any commentary lemmas, cf. Classen 2003, 14-15.

11 The editio princeps was published in the Officina Frobeniana in March 1528: De recta Latini Graecique sermonis pronuntiatione Erasmi Roterodami Dialogus. Eiusdem dialogus cui titulus Ciceronianus seu De optimo genere dicendi; cum aliis nonnullis quorum nihil non est nouum, Basileae: Hieronymus Froben, 1528.

12 The only ancient commentary to Cicero's speeches that was surely known to fifteenth-century Italian scholars was that of Asconius Pedianus, which (after its rediscovery by Poggio Bracciolini) began to circulate from 1416 onwards. It was printed regularly, often together with contemporary commentaries, but of course only for the small number of speeches it contains, most importantly Pro Milone.

13 Cf. Pade 2007. 
which provided the commentators with the bulk of historical details, especially the Lives of Caesar, Mark Antony and Brutus, together with Leonardo Bruni's version of the life of Cicero, the Cicero nouus (officially a translation, but in fact a free adaptation of Plutarch's Cicero). ${ }^{14}$

I offer only one example for the commentators' dealing with their source material. It is a passage from Maturanzio's historical introduction to the Philippics (the other two commentators do not have a similar historical account): after Caesar had been killed by 24 wounds (not 23 !) ${ }^{15}$ and the conspirators have occupied the Capitol, Maturanzio describes the following events in a kind of pastiche of several Plutarchan Lives. I have underlined passages which either quote or are closely inspired by Guarino da Verona's translation of the Life of Brutus, italicized references to Leonardo Bruni's translation of the Life of Mark Antony, and printed in bold what stems from Bruni's Cicero nouus: ${ }^{16}$

Iccirco timens Antonius consulatus ${ }^{17}$ abiectus insignibus et mutata ueste ${ }^{18}$ delituit. uerum quando nemini illos nocere accepit tutaque esse omnia, prodiit e latebris. Senatus in Telluris aede habitus est. Multa pro concordia facta sunt uerba. ${ }^{19}$ Cicero illico princeps in illo ordine apparuit: cum recuperata libertas uideretur esse, ${ }^{20}$ pacem inter amicos et interfectores Caesaris qui Capitolium occupauerant suasit, discordiarum memoriam sempiterna obliuione delendam censuit. Brutus et Cassius laetis omnibus ${ }^{21}$ e Capitolio uocati non prius tamen descendere quam Antonius et Lepidus uterque filium suum obsides pro illis in Capitolium mitterent. ${ }^{22}$ Et C. quidem Cassium coenae die illo Antonius, Lepidus Brutum adhibuit. Postridie uero eius diei, cum de obliuione discordiarum, de prouinciis diuidundis Antonius retulisset, summo studio ei senatus assensus est, etiam ut Caesaris acta rata

14 See Mabboux and Jansen in this volume for more details.

1523 is the number offered by all ancient sources, e. g. Plut. Caes. 66.14, Livy, Per. 116 or Flor. 2.13; also the editio princeps [Rome 1470] of all of Plutarch's Lives in Latin translations offers this number, cf. Plutarch 1470, fol. 363v (the Life of Caesar in the translation by Guarino da Verona). 16 The passages in the editio princeps (Plutarch 1470) are on fols. 402r (Life of Brutus) and 443r (Life of Mark Antony); the Cicero nouus is quoted according to Viti's 1996 edition, 486.

17 consulatus] magistratus Plutarch 1470 (Bruni).

18 The same is also in Life of Brutus (in: Plutarch 1470 [Guarino]).

19 In Guarino's version of Plutarch's Life of Brutus (in: Plutarch 1470) Antony, Plancus and Cicero are mentioned as main orators.

20 Maturanzio reuses this formulation almost verbatim in his introduction to the second Philippic: Bade 1529, fol. 24v: ciuitatis eo tempore princeps.

21 This summarizes Bruni's longer wording: Brutus et Cassius a senatu laudati; gratulationes et applausus ut liberatoribus patrie per totam urbem facti (Bruni, Cic., 486).

22 This episode is also in Life of Brutus (in: Plutarch 1470 [Guarino]); Maturanzio has summarized both versions relatively freely rather than simply quoting one of them, as is the case in the other highlighted references. 
manerent. Magnam tunc omnium iudicio laudem est consecutus quod intestinum sua prudentia sustulisset bellum et recto consilio ac ciuili animo usus esset. ${ }^{23}$

Therefore Antony was afraid; he dropped the decorations of his consulship and hid after having changed his clothes. But when he heard that they [sc. the murderers of Caesar] did not want to harm anyone and that everything was safe, he stepped out of his hiding place. The senate was gathered in the temple of Tellus; many words in favour of concord were uttered. Immediately Cicero appeared to be the leader of this body: because freedom seemed to be restored, he recommended peace between the friends and the killers of Caesar, who had taken possession of the Capitol, and he promoted that the memory of discord should be extinguished into eternal oblivion. With everyone's approval Brutus and Cassius were called from the Capitol, but they did not descend before Antony and Lepidus had both sent their sons as hostages to the Capitol. And Antony invited C. Cassius to dinner that day; Lepidus did the same with Brutus. Moreover, the next day, when Antony spoke about the amnesty of the discord and about the distribution of the provinces, the senate very eagerly agreed with what he said, also in that the acta Caesaris remained valid. On that occasion, according to all, Antony deserved great praise for having suspended an imminent civil war with his intelligence and for having shown his right intention and his civil spirit.

It is a striking proof of Maturanzio's historical honesty that he has not omitted the very positive evaluation of Antony here. ${ }^{24}$ Generally, however, he seldom distances himself from Cicero's eulogistic auto-representation; his aim is to extol the Roman orator and politician as much as he can. In this attempt he can be connected to earlier humanistic reappraisals of Cicero as a major political actor of his time, e. g., Leonardo Bruni's Cicero nouus or Sicco Polenton's description of Cicero. ${ }^{25}$ His aim is to show that Cicero in the years 44 and 43 was ciuitatis eo tempore princeps (cf. n. 20), whose engagement the other Romans would have expected anxiously. In order to do so, he suppresses any criticism of Cicero's behaviour (as the attack on his constantia which Atticus had launched when Cicero wanted to leave Italy in the summer of 44, and against which he had defended himself in Att. 16.7). Instead Maturanzio describes the event as a completely straightforward decision by Cicero, who only reacted to the always changing

23 Bade 1529, fol. a ii v.

24 E. g., the Paduan humanist Sicco Polenton in his long and detailed narration of the events deals with Mark Antony's speech, but does not mention that he was praised for it. Instead the people of Rome attribute the glory for having restored the state to Cassius and Brutus, cf. Polenton, Script. ill. (= Polenton 1928), 413.

25 Think of Sicco Polenton's seven (!) books dedicated to Cicero's life in his Scriptores illustres Latinae linguae. As he puts it, Cicero's life and works are an ingens opus et mare, an ocean of material testifying to the mass of his deeds (rerum magnitudo) and to his dignity (uiri dignitas): cf. Polenton, Script. ill. (= Polenton 1928), 265. See Mabboux and Jansen in this volume for the development between the thirteenth and early fifteenth century. 
moods of Antony. ${ }^{26}$ In order to increase Cicero's courage, he adds a small detail which deviates from both the ancient sources and the biographical tradition of the fifteenth century. According to him, Cicero actually dared not only to deliver his second Philippic in the senate, but he even did so in Antony's presence: Ausus est uenire in senatum et hanc orationem, qua omnem ante actam Antonii uitam carpit et lacerat, habere ipso Antonio praesente et audiente. ${ }^{27}$ However, such a deviation from the sources is quite rare. In general, Maturanzio's dependence on his ancient and humanistic predecessors testifies to the deep rootedness of early modern commentaries in humanistic literary culture, a fact that increases also the layeredness of Bade's 1529 edition: it not only preserves earlier commentaries, but also the larger fifteenth-century debate and its ancient roots on Cicero's political and oratorical exemplarity.

\section{The Philippics as Cicero's Spätwerk}

When an author wants to show Cicero's exemplarity, the Philippics traditionally take pride of place in his argument. They have been considered part of Cicero's Spätwerk, that is, an opus ultimum that condenses his life-long oeuvre in a special way and helped turn its author into a 'classical' writer. ${ }^{28}$ In principle the concept can refer to style or content. Whether there are indeed certain traits in the Philippics that justify labelling them as representatives of a distinct Spätstil is open to discussion. Recently, Michael von Albrecht has defended its existence: ${ }^{29}$

26 With regard to Antony, Maturanzio had already alluded to mutata mox eius uoluntas previously; Cicero's decision to return to Rome and not leave Italy is presented as follows: Reuertendi in urbem nouum cepit consilium cum mutatam Antonii uoluntatem intellexisset et repudiatis malis suasoribus se ad senatus auctoritatem totum contulisset [correxi, contulisse Bade 1529]. He again bases this on Bruni, who stresses Antony's mutata uoluntas/mutatio at exactly the same historical moments (Bruni, Cic., 486 and 488).

27 Bade 1529, fol. 24v. Bruni, Cic., 490 says that Cicero wanted to go to the senate and respond to Antony's invective, but his friends dissuaded him. Sicco Polenton does not comment on the setting of the speech.

28 Cf. recently, e.g., Scheidegger Lämmle 2016 and Bitto 2016. According to them, a Spätwerk on the one hand is particularly susceptible to authorial self-stylization (e. g., the Spätwerk can channel the reception of earlier works), on the other hand is something to which later readers often recur in order to find coherence in the corpus of an author. I am grateful to Ermanno Malaspina for having reminded me of the importance of the concept for Cicero's works dating from 44/43 BCE. For Cicero's own attempt to become a 'classic', see Bishop in this volume.

29 His summarizing characterization, however, makes use of a terminology that seems even more typical for describing an Alterswerk than a Spätwerk; cf. Scheidegger Lämmle 2016, 65 for the distinction. 
according to him, Cicero has freed himself from juvenile exuberance and thus achieves the highest degree of stylistic balance. ${ }^{30}$ Similarly, Josse Bade, whose edition of 1529 will be analysed in this article, states that Cicero, the master of eloquence, surpassed even himself in the Philippics:

Vt enim ille omnium mortalium calculo et suffragio in eloquentia togatorum facile euasit primus aliosque in aliis operibus dicendi felicitate euicit omnes, ita in hoc opere se ipsum idest humanas uires superasse [...] uisus est. ${ }^{31}$

Just as according to the calculation and vote of all mortals he was easily the first in the field of eloquence of the Romans and defeated in his other oratorical works all others, thus in this work he seems to have defeated himself, that is human nature.

On the other hand, early modern readers were also willing to read the Philippics as Cicero's political heritage. This is partly due to Cicero's own rhetorical strategy in the speeches themselves, in which he shapes his ethos in a way that re-evokes his consular and post-consular auctoritas, thus stressing his political constantia as defender of the good cause of the Republic ever since his fight against Catiline. ${ }^{32}$ At the same time, he already reflects on his final works as part of a future commemoration of his deeds. ${ }^{33}$ In the first Philippic Cicero wants to leave his voice as a testament for the state (ut [...] huius tamen diei uocem testem rei publicae relinquerem, Phil.1.10), ${ }^{34}$ and the end of De officiis refers to his voice which reaches his son Marcus, who is dwelling in Athens, his uoluminibus, i.e., in the written work itself (quoniam his uoluminibus ad te profecta uox est mea,

30 Cf. von Albrecht 2003, 114: "a general increase in purism, suppression of showy ornaments, strength and transparency instead of abundance". Cf. the epilogue to this volume for Erasmus' initializing the debate about a Ciceronian Spätstil.

31 Bade 1529, fol. <A ii v>. The text of the preface is edited in Renouard 1908, vol. 2, 323 (who erroneously prints humanitas instead of humanas). A French translation can be found in Lebel $1988,120-122$.

32 Cf., e.g., May 1988, 149; see also the famous beginning of Cic. Phil. 2: Quonam meo fato, patres conscripti, fieri dicam, ut nemo his annis uiginti rei publicae fuerit hostis, qui non bellum eodem tempore mihi quoque indixerit? Ps-Trapezuntius' commentary ad loc. reads as follows (Bade 1529, fol. 24r): Hoc tamen affirmatiue dicit: fato uideor esse susceptus et natus ut omnes reipublicae hostes qui fuerant his annis uiginti, mihi etiam fuerint hostes, thus adding an idea of Cicero's consistency as a result of the intervention of fate. Maturanzio makes Cicero's sentence unambiguous by explaining that Cicero's enmity against Catiline, Clodius, Antony and others was undertaken magis reipublicae quam priuata causa (ibid., fol. 24v).

33 Cf. Bishop in this volume on Cicero's attempts to turn himself into an object of commemoration.

34 For this passage see also Scheidegger Lämmle 2016, 105. On the importance of writing in Cicero's oeuvre, see Butler 2002; Jansen/Pieper/Van der Velden (forthcoming). 
Off. 3.121). This wish to codify his political ethos for future generations fits well the "Poetik des Nachlasses" as defined by Scheidegger Lämmle. ${ }^{35}$

Also in Bade's praise of Cicero's rhetorical excellence which I have just quoted, an intertextual link, going beyond mere stylistic appreciation, adds a political aspect to his recognition of the Philippics as Cicero's Spätwerk. Bade refers to Cicero's own words with which he had remembered the death of Crassus in the preface of De oratore $3 .^{36}$ Cicero's Crassus is not just a master of technical rhetoric. His last speech against consul Philippus was so excellent because in it he professed his political legacy as defender of the old senatorial values. ${ }^{37}$ The link alludes to a similar function of the Philippics, which also serve as the political testament of a defender of the old Republican values. Just like Crassus, Cicero paid for his oratorical triumph with his life, a fact that lends extra gravity to the speeches.

Bade was surely not the only Renaissance reader of the Philippics to adorn the speeches with the aura of 'last words'. Angelo Poliziano, whose fragmentary annotations to the Philippics we possess thanks to the notes taken by Poliziano's student Pietro Crinito, ${ }^{38}$ makes the same link with Crassus' death via a reference to the famous image of the swans' song before their death: ${ }^{39}$

35 Scheidegger Lämmle 2016, 66, quoting Zanetti 2012, 54, who talks of the "Begehren [...] das bisher Geleistete im Hinblick auf die künftige Rezipierbarkeit des Geschriebenen insgesamt zu sichern oder in neue Bahnen zu lenken”.

36 Cic. De or. 3.3: Omnium consensu sic esse tum iudicatum ceteros a Crasso semper omnis, illo autem die etiam ipsum a se superatum.-In connecting Cicero's death to his De oratore, the humanist readers might be inspired by a tradition from Antiquity, which we can grasp in the description of Cicero's end by the Tiberian historiographer Cremutius Cordus: he links Cicero's death to the death of the second protagonist of De oratore, Marcus Antonius the orator (Sen. Suas. 6.19): Itaque, quo saepius ille ingenti circumfusus turba processerat, quae paulo ante coluerat piis contionibus, quibus multorum capita seruauerat, tum per artus sublatus aliter ac solitus erat a ciuibus suis conspectus est. (cf. De or. 3.10: Iam M. Antoni in eis ipsis rostris in quibus ille rem publicam constantissime consul defenderat quaeque censor imperatoriis manubiis ornarat, positum caput illud fuit a quo erant multorum ciuium capita seruata). Also Livy might allude to this passage in the fragment narrating Cicero's death (Sen. Suas. 6.17): Caput in rostris [...] positum ubi ille consul, ubi ille consularis [...] auditus fuerat.

37 Cf. the direct continuation of the passage quoted in n. 36 (De or. 3.3) which gives the reason (enim) for Cicero's judgment: Deplorauit enim casum atque orbitatem senatus, cuius ordinis a consule, qui quasi parens bonus aut tutor fidelis esse deberet, tamquam ab aliquo nefario praedone diriperetur patrimonium dignitatis.

38 The manuscript has been studied by Mussini 2013.

39 Cf. Cic. De or. 3.6: Illa tamquam cycnea fuit diuini hominis uox et oratio. Scheidegger Lämmle 2016, 87-92 and 99-102 discusses the importance of the image in De or., Rep. and Amic. 


\begin{abstract}
Nam profecto nemo dubitat omnes in ea uel animi uel ingenii sui neruos intendisse Ciceronem, sic ut alios in ceteris, in hac actione se ipsum maximus orator superauerit. Adsumam quod cignos ait Plato sacros Apollini suauissime canere morti uicinos: hoc utique transferri aptissime ad Ciceronem potest, cuius hic liber tanquam extremus actus boni poetae supra ceteros laudetur. ${ }^{40}$
\end{abstract}

For assuredly no one doubts that Cicero concentrated all the energy of his mind and talent in them [sc. the Philippics], so that the greatest orator surpassed others in other speeches, but himself in this one. I adopt what Plato says: swans, holy animals of Apollo, sing most sweetly when death is near. No doubt that this can most aptly be applied to Cicero, whose last book (the one we treat here) is praised more than all the others, like the final performance of a good poet.

One of the commentators edited by Bade in 1529, Filippo Beroaldo, also argues in a similar direction. He dedicates much space in his introduction to the ancient declamations dealing with Cicero's enmity with Antony and his death (see p. 190), ${ }^{41}$ thus creating a shadow of an imminent end around the Philippics. In the commentary itself he returns to this frame in two prominent places. In his last lemma of the first speech, when commenting on Cicero's sentence "The life I have lived is almost enough for me regarding both my age and my glory" (mihi fere satis est quod uixi uel ad aetatem uel ad gloriam, Phil. 1.38), he relates this to Cicero's actual death and quotes the "declaimer Cestius [Pius] who has said: 'If one looks at the longing of the people, you, Cicero, when you will die, have not lived long enough; if one looks at your deeds, you lived long enough; if one looks at the inequities of destiny, you have lived too long; is one looks at the memory of your works, you will live forever'”. (Cestius declamator egregie dixit: "Si ad desiderium populi respicis, Cicero, quando perieris parum uixisti; si ad res gestas, satis uixisti; si ad iniurias fortunae et praesentem reipublicae statum, nimium diu uixisti, si ad memoriam operum tuorum, saepe uicturus es", Sen. Suas. 6.4). The close relation between Cicero's death and his immortal fame is very reminiscent of a Spätwerk-discourse. More specifically, the formulation that Cicero has lived too long and therefore has seen the harshness of destiny alludes again to Cicero's own description of Crassus' death, who in Cicero's words had been spared from seeing the horrors of civil war due to a timely death.

40 I quote the text from the edition by Mussini 2013, 223, lines 27-31. As Mussini also notes, the end of the passage (tanquam extremus actus boni poetae) quotes Leonardo Bruni's Cicero nouus (Ciceronis uelut optimi poete extremus actus, Bruni, Cic., 488), who however does not relate this to the Philippics alone, but to Cicero's final year after his return to Rome in September 44 BCE. Cf. on this specific passage Jansen in this volume, pp. 167 and 172.

41 For the important role of declamation in the early reception of the Philippics see Keeline and Bishop in this volume; cf. also Keeline 2018 and La Bua 2019. 
Attributing glory to Cicero's death is surely something Beroaldo was interested in. In one of the last lemmas of his commentary, on Phil. 14.34, he writes:

ID GENVS QVOD EST ${ }^{42}$ PVLCHERRIMVM ] Socrates apud Platonem sic sermocinatur: "Videtur, Menexene, apud plurimas gentes praeclarum esse in bello occumbere. Etenim qui sic e uita migrat, funere et sepulchro magnificentissimo honoratur". ${ }^{a}$ Epaminundas Thebanus dicere

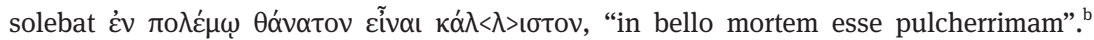

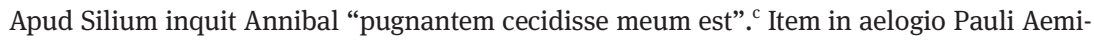
lii "tibi gloria laeto $\left[\right.$ sic] | iam parta insigni”. ${ }^{\mathrm{d}}$ Plato quoque ita refert: "Profecto cum liceret nobis turpiter uiuere, honeste mori maluimus". ${ }^{43}$
a. Pl. Menex. 234c
b. b. Plut. Mor. 192c = Apophth. regum 72.1
c. c. Sil. Pun. 4.509
d. d. Sil. Pun. $10.573-574$
e. e. Pl. Menex. 246d

THIS KIND WHICH IS MOST BEAUTIFUL] Socrates speaks as follows in the work of Plato: "Menexenus, to die in war seems splendid for most nations. For who passes away like this, is honoured by a very magnificent funeral and tomb". The Theban Epameinondas used to say that "death in war is most beautiful". Hannibal says in Silius Italicus that "it is my task to fall fighting”. See Silius, in Aemilius Paulus' eulogy: "your praise has emerged already through your glorious death [leto]". And Plato says the following: "Indeed, when we were allowed to live a disgraceful life, we preferred to die honourably".

Cicero is here talking about those who have left their lives in the battle against Mark Antony and who will receive not only an honorific funeral monument, but also-more importantly-eternal fame. But Beroaldo's explanation could also be read as an indirect laudatio funebris of Cicero, who according to tradition had not only died during, but also because of his battle against Antony. ${ }^{44}$

All these strategies by the commentators help to present the Philippics as something special: they are Cicero's rhetorical and political legacy, a kind of condensation of his work, and they are especially ennobled by the high price he had to pay for them.

42 Modern editions print esset here.

43 Bade 1529, fol. 177r.

44 For a more nuanced assessment of Cicero's death, see Keeline in this volume. 


\section{The interplay between the three commentators: fine-tuning the veneration for Cicero}

While the reading of the Philippics as a kind of Spätwerk was obviously shared by most commentators in the fifteenth and early sixteenth century, in other instances, commentators also reacted specifically to one another. Bade's edition with the triple commentary makes it possible for his readers to compare the lemmas of different learned men and to look for similarities and differences. Before turning to some instances demonstrating this, however, it is useful to recall that an edition with several commentaries was nothing special per se-it was common practice at the beginning of the sixteenth century to publish Horatius cum quattuor commentariis (Venitiis: [Bon. Locatellus] 1494, with several reprints in the sixteenth century), Vergilius cum quinque commentariis (Argentorati: Joh. Grüninger 1502, with several reprints) and so on. Obviously, these large editions were not meant to be schoolbooks. They allowed more mature readers to compare the commentaries and to make up their own minds, especially in cases where the commentators entered into implicit or explicit discussion with each other.

Bade was one of the champions in this field. As Mark Crane has argued, his aim was to foster his readers' intellectual independence: "Bade's commentaries thus reflect faith in the capacity of his readers to use them in their full potential without having a teacher looking over their shoulder". ${ }^{45}$ In this he might have been inspired by Beroaldo, one of his teachers during his Italian years, whom he continued to revere throughout the rest of his life. ${ }^{46}$ The confronting of different commentaries was typical for Beroaldo as well: in commentaries that he published alone, he often explicitly quoted entries by his predecessors. It was also his decision to publish his commentary on the Philippics in 1501 together with Maturanzio's already existing one, thereby enabling the readers to choose the 'true' explanation, as he himself declares programmatically in his edition of Propertius from 1491 with the help of a quotation from Jerome (In Ruf. 1.16). He argues that the commentator's task is "to exhibit the interpretations of many so that an intelligent reader when reading the different explanations can judge what is true" (multorum sententias exponere ut prudens lector cum

45 Crane 2012, 108.

46 Cf. White 2013, 17-18. 
diuersas explanationes legerit, iudicet quid uerius sit). ${ }^{47}$ The quotation shows Beroaldo's wish to engage the reader actively in the process of reading by offering him alternative explanations.

The same approach is also valid for Bade's edition of the Philippics. One can find passages that are so closely related that I am inclined to label them conscious intertextual references between the three commentators printed by Bade. I quote the three individual introductions to the second Philippic. Pseudo-Trapezuntius writes: Haec est secunda Philippica quae Ciceroni mortem attulit. Respondet autem criminibus et maledictis Antonii, deinde uehementissime et acerbissime in eum inuehitur. ${ }^{48}$ ("This is the second Philippic, which brought death to Cicero. He responds to Mark Antony's crimes and vituperations, and then accuses him very fiercely and violently"). Maruranzio, whose function as professor of rhetoric in Perugia makes it very probable that he knew a commentary attributed to a famous rhetorician such as George of Trebizond, imitates the emphatic beginning with a demonstrative pronoun that immediately appeals to the reader's emotional engagement with the text: Haec est secunda Philippica quae M. Antonium priore oratione uehementer commotum in Ciceronem accendit ut leniri odii atrocitas postea numquam potuerit. Exstitit autem exitii et mortis Ciceroni causa, dicente etiam satyrico poeta, "Ridenda poemata malo / quam te diuinae miranda Philippica famae / uolueris a prima quae proxima" ${ }^{49}$ ("This is the second Philippic, which angered Mark Antony, already very unsettled because of the first speech, so much that afterwards his hatefulness could never be mitigated again. It was also the reason for Cicero's death, as the satirical poet also asserts: 'I rank his ridiculous verses above you, astonishing Philippic, next to the first on the roll, with your immortal reputation"'). Beroaldo in his turn was one of the most learned men of his time (his phenomenal memory was praised by many fellow humanists) and one of the most successful teachers of Italy in his generation; therefore he will most probably have known not only Maturanzio's, but also the earlier Venetian edition of Pseudo-Trapezuntius. Beroaldo also makes use of the emphatic beginning haec est and, like Maturanzio, immediately refers to Juvenal as an ancient authority for the almost divine perfection of the speech: Haec est illa Philippica omnibus Antonianis anteponenda, quam diuinam esse merito appellant, de qua sic serio scripsit poeta satyricus, "Quam te conspicuae

47 Quoted after Grafton 1977, 187 and Maréchaux 1997, 117. Grafton 1977, 188 has interpreted this as Beroaldo's unwillingness to express his own opinion and an invitation to "deplorably slovenly habits” (see also id. 1985, 636-637). Sandy 2007, 417, however, argues that Grafton’s view is probably overstated.

48 Bade 1529, fol. 24r.

$49 \mathrm{Ibid}$. The quotation is Juv. 10.124-126. 
diuina Philippica famae / uolueris a prima quae proxima".50 ("This is the famous Philippic, which one must prefer to all other Antonian speeches, and which one has rightly labeled 'divine'. The satirical poet seriously writes about it '[I rank his ridiculous verses above] you, immortal Philippic, next to the first on the roll, with your distinguished reputation”").

The addition of the adverb serio could be regarded as a reaction to Maturanzio, a clarification that Beroaldo deems necessary: Juvenal here does not speak with his usual satirical irony. This observation is especially striking if we consider that Beroaldo's commentary was always printed together with that of Maturanzio and that it might even have been triggered by his reading of the latter's work. ${ }^{51}$ The reader is not only able, but invited to read the two almost identical versions next to each other. To be sure, a correction as the one just mentioned is rare in the running commentary where Beroaldo and Maturanzio often comment on different words or do it in very different manner. ${ }^{52}$ It seems exaggerated, however, to conclude from this, as Maria Teresa Casella in a groundbreaking article from 1975 has done, that "nessun dialogo s'istaura tra i due commentatori". ${ }^{53}$ There are several passages, especially in the introductions to the speeches, where Beroaldo's wording reacts to what he has read in Maturanzio. But the effect of this coexistence of the two commentators (or three, if we also take into account the much shorter annotations by Pseudo-Trapezuntius in Bade's edition) is not always that of a free choice for the reader; it can also enforce the preferred interpretation. In the case of the prefaces to the second Philippic, the commentaries drum the conveyed message (Cicero's second Philippic is a divine piece of oratory) into the readers' heads by means of persuasive repetition.

In order to corroborate this finding, let us turn to Maturanzio's and Beroaldo's praise of the Philippics in their respective introductions to all speeches. Maturanzio, who in his lemmas is usually more wordy than Beroaldo, keeps the lau-

50 Bade 1529, fol. 25r. The textual difference in the quotation from Juvenal is already in the 1513 edition (the editio princeps of Beroaldo's commentary), fol. Xv-XIr-obviously Beroaldo wanted to represent Maturanzio's commentary as accurately as possible; the same then goes for Bade with regard to both Beroaldo and Maturanzio. The content of the verse is only slightly different: in Maturanzio's version, the glory of the second Philippic is divine; in Beroaldo's version (which corresponds to modern editions), it is the speech itself.

51 Thus Casella 1975, 654.

52 Cf. ibid., 655, where Casella calls the interaction between the two a "mosaico in cui frammenti si allineano, non si sovrappongono" (but see my relativizing remark below). As mentioned above, Maturanzio's commentary is often more antiquarian or historical in tone, e.g. the two longest entries for the beginning of Philippics 1 are on patres conscripti (with the history of this term since Romulus), and on the fake-Marius (with a long summary of the events).

53 Ibid., 654. 
datory introduction quite short. ${ }^{54}$ He briefly mentions four aspects: Cicero's imitation of and admiration for Demosthenes, the alternative name of Antonianae orationes transmitted by Aulus Gellius (e.g. NA 1.22.17; 6.11.3), and the speeches as the reason for Cicero's death, which is confirmed with a quotation from Juvenal (10.121-126). Additionally, at the beginning of his historical overview (see above, p. 179), he remarks that some of them were delivered in the senate, while others were speeches ad populum. In contrast to Maturanzio's brevity, Beroaldo's introduction is unusually long-he writes more than four times as many words, but he does not enlarge on all aspects in the same way. He says nothing about the audience of the speeches, only mentioning the name Antonianae orationes in passing (without reference to Gellius). His discussion of Cicero's dependence on Demosthenes is not much longer than Maturanzio's, but formulated more radically. The Perugian scholar quotes Cicero's Orator with the sentence that Demosthenes fulfilled what Cicero only aspired to (et Demosthenem quidem ad Brutum scribens multa et in dicendo perficere, se conari multa, posse illum, uelle se dicit). ${ }^{55}$ Beroaldo in his turn begins his introduction with two sentences in which Cicero's name is not even mentioned; instead, Demosthenes is introduced with Quintilian's words as the lex orandi (Inst. 10.1.76). Cicero is afterwards introduced as an imitator of the Greeks and of Demosthenes in particular:

M. Tullius cum se totum ad imitationem Graecorum contulisset, maxime Demosthenem est aemulatus. Illum habet archteypon exemplar, illum cum primis admiratur eumque omni praeconio laudis extollit. Cuius nomini ac paene numini tantum tribuit ut orationes in M. Antonium triumuirum stilo bellatorio fulminantes Philippicas appellauerit quae et Antonianae nominantur. In quibus non minus clarum quam in forensibus orationibus eloquentiae lumen effulget. ${ }^{56}$

Because Marcus Tullius resorted completely to the imitation of the Greeks, he especially emulated Demosthenes. He considers him his archetype and model, he especially admires him and praises him in all possible ways. He attributes so much to his name and (so to speak) godlike status that he gave the name Philippics to the speeches that thunder in warlike style against Mark Antony; they are also called Antonianae orationes. The light of his eloquence does not shine less brightly in these than in his judicial speeches.

The lumen which Cicero's speeches are said to possess thus seems to be dependent on his imitation of Demosthenes. The first impression the reader gets of Cicero is not that of the father or even name of eloquence, but of a sort of prede-

54 Bade 1529, fol. a ii r.

55 Ibid. quoting Cic. Orat. 105; cf. Bishop 2015, 286.

56 Bade 1529, fol. a i r. 
cessor of the humanists who through imitation has achieved the highest oratorical glory.

But the longest part of Beroaldo's introduction is still to come. He indulges at length in the theme of Cicero's death as a consequence of the speeches. The material he adds to Maturanzio's short notice stems from declamation (Seneca's sixth and seventh Suasoriae which treat the theme of whether Cicero should have burnt his speeches in order to save his life) ${ }^{57}$ and historiography (Livy's description of Cicero's death as again transmitted by Sen. Suas. 6.17). Beroaldo quotes long sections of his sources verbatim, but two passages where he interrupts Livy's account are revealing. First, he presents the reader with a second version of Cicero's 'last words' (as transmitted by Aufidius Bassus, Sen. Suas. 6.18)..$^{58}$ Second, he adds a quote by Mark Antony (which he found in a fragment of Cremutius Cordus, Sen. Suas. 6.19) that with Cicero's death the proscriptions have been fulfilled: peracta proscriptio est. These additions are in no way meaningless. In the first case, Beroaldo introduces his addition in a pathetic way with the particle ecce and by addressing Cicero in the second person (tibi), arguably in order to enlarge the reader's involvement and sympathy with Cicero at the moment of his death. The second addition is even more interesting. Antony's triumphant sentence seals Cicero's exceptional role: the whole proscription seems to have been undertaken only in order to have him murdered, and his death ends the bloodshed. The consequence remains implicit: if Cicero had refused to die, but had fled instead, the proscription would have continued and more Romans would have been killed. This means that Cicero, whose speeches during his lifetime according to Cremutius Cordus (Sen. Suas. 6.19) had saved the lives of many (multorum capita seruauerat), saves Roman lives even with his death.

What we see in Beroaldo's introduction is a reaction to Maturanzio's introduction: Cicero's oratorical pre-eminence is somewhat relativized by Beroaldo stressing his dependence on Demosthenes. On the other hand, the importance

57 On the importance of declamation for the reception of Cicero's final years see Keeline and Bishop in this volume.

58 Bade 1529, fol. a i v (the underlined passage is an addition to Seneca's words by Beroaldo): Regressusque in uillam "Moriar", inquit, "in patria saepe seruata". Satis constat seruos fortiter fideliterque paratos fuisse ad dimicandum. Ipsum deponi lecticam et quietos pati quod fors iniqua cogeret iussisse. [Livy] Ecce tibi adest Popilius, olim a Cicerone defensus! Quem cum armatis militibus postquam aduentare prospexit "Accede”, inquit, 'ueterane, et incide ceruicem”. [Aufidius Bassus] ("And returning to his villa, he said: 'I will die in the fatherland that I have saved so often'. It is well known that his slaves were ready to fight bravely and faithfully. He himself told them to put down the litter and to suffer calmly what an evil destiny had ordained. See, there comes Popilius, once defended by Cicero! When he saw him arriving with armed soldiers he said: 'Come here, veteran, and cut through my neck'.”). 
of the Philippics as the testament of an exceptional political figure is enlarged. Beroaldo probably did this on purpose. He was an 'Apuleianist' and was as such opposed to the uncritical veneration of Cicero as a stylistic model by the 'Ciceronians' of his time. ${ }^{59}$ As humanistic role model for political engagement and moral behaviour, however, Cicero remained very much acceptable.

\section{Bade's preface: adding a Christian flavour}

As we have seen so far, Josse Bade's edition offers the reader a temporally layered "delineazione di alcuni aspetti di storia della filologia", as Donatella Coppini has defined it: three Italian Quattrocento commentators, who all belong to different "generazion[i] filologic[he]" and who incorporate older material in their commentaries, ${ }^{60}$ embedded in the context of a sixteenth-century edition. As mentioned before, Bade's own philological additions are few, but his preface to the edition is often considered to be one of his most important paratexts; according to Paul White, it is "the only document in which Badius reflects on his own contribution and legacy to the world of scholarship". ${ }^{61}$

The text has the form of a dedicatory letter "to the admirer of Ciceronian expression, that is of the whole Roman eloquence" (Iodocus Badius Ascensius Ciceronianae phraseos, id est totius eloquentiae Romanae miratori studioso salutem). ${ }^{62}$ The letter can be divided into two parts. In the shorter second one, in which Bade pays tribute to Cicero (a passage partially quoted above, p. 182), he qualifies Beroaldo's evaluation that Cicero was a (mere) imitator of Demosthenes. According to Bade-whose admiration for Beroaldo did not prevent him from being a Ciceronian stylist ${ }^{63}$-Cicero was not inferior to the champions of Greek eloquence:

Vt enim ille omnium mortalium calculo et suffragio in eloquentia togatorum facile euasit primus aliosque in aliis operibus dicendi felicitate euicit omnes, ita in hoc opere se

59 Cf. D’Amico 1984, esp. 361-362; Rose 2001, 59-63.

60 Coppini 1976, 1371.

61 White 2013, 58. More generally, Diu 1997, 116 has underlined the importance of Bade's prefaces: “C'est à l'occasion de ses préfaces que Bade forge son image de lettré”; “il s’y présente [...] comme champion de la restauration des belles-lettres".

62 Bade 1529, fol. $\langle$ A ii $r$.

63 See Deneire 2011, 26-27. 
ipsum idest humanas uires superasse et cum principe Graecorum Demosthene dubia de uictoria contentione certasse uisus est. ${ }^{64}$

Just as according to the calculation and vote of all mortals he was easily the first in the field of eloquence of the Romans and defeated all in his other oratorical works, thus in this work he seems to have defeated himself, that is human nature, and fought against Demosthenes, the best of the Greeks, in a battle the winner of which is undecided.

In the first part of the letter, however, Bade adds a religious level to his commentary. Its main aim, so he says, is not to propagate classical education for its own sake, but to render the reader capable of true Christian faith:

\begin{abstract}
Totis cum corporis tum animi uiribus retinere conatus sum, ut uidelicet pro uirili mea et talento mihi a deo credito per litterarum promotionem rem christianam iuuarem. Visum enim mihi fermeque persuasum erat ut quisque optime Hebraice, Graece aut Latine sciret, ita ad diuinorum eloquiorum intellectionem esse et fuisse semper aptissimum. ${ }^{65}$

With all the energy of my body and intellect I have tried to be loyal to my principles, that means to help promote Christian faith as well as my power and talent (which God has given me) allowed me. I thought and was almost sure that the more anyone had deep knowledge of Hebrew, Greek and Latin, the more he would be and would always have been well prepared to understand the divine utterances.
\end{abstract}

Bade defines nuanced knowledge of Christian Scripture as being dependent on a good training in classical, i.e. non-Christian rhetoric, and thus makes a strong claim for the latter's importance. Cicero, the champion of eloquence, is therefore a crucial author for all Christians to study. On the other hand Bade thereby reduces classical rhetoric to a propaedeutic discipline for theological studies. ${ }^{66} \mathrm{Ob}$ viously, this argument goes back to discussions in Late Antiquity on how a Christian believer had to deal with non-Christian authors. Bade makes the link explicit by mentioning Greek and Roman church fathers as his witnesses, among them Hilary of Poitiers, Jerome, Ambrose, Augustine sexcentique alii. Hilary, for example, had declared that one had to use the most rhetorically polished language when speaking about the marvels of God's greatness. ${ }^{67}$

64 Bade 1529, fol. <A ii v>. For the ancient tradition of staging a fictitious competition between Demosthenes and Cicero, see De Jonge 2019.

65 Bade 1529, fol. <A ii r>. Cf. Renouard 1908, vol. 2, 323, who prints saepe instead of semper. 66 Cf. Crane 2012, 109 on the difference between Erasmus and Bade: the latter according to him was a propaedeutic thinker, whereas Erasmus was a critical spirit.

67 Hilary, Tractatus super Psalmos 13.1: Quanto magis conuenit Dei eloquia ad cognitionem humanam retractantes dignos nos hoc officio praestare! Sumus enim quoddam sancti spiritus organum, per quod uocis uarietas et doctrinae diuersitas audienda est. Vigilandum ergo et curandum est, ut nihil humile dicamus metuentes huius sententiae legem: 'maledictus omnis faciens opera 
The old debate gained renewed relevance at the beginning of the sixteenth century. Erasmus had defended the integration of classical learning in his Antibarbari of 1520. More importantly, in 1528, one year before Bade published his commentary, in Erasmus' Ciceronianus the character Bulephorus (who functions as Erasmus' spokesman) defended a Christian rhetoric that was based on a fluid combination of Cicero and Paul, i.e. of Roman and Christian persuasion at the same time. ${ }^{68}$ Bade, who had been influenced by the deuotio moderna of Thomas a Kempis in his youth, already in his commentary to Terence had declared that real poetry was always inspired by the Holy Spirit. In 1529, towards the end of his career as a printer, he programmatically re-affirms his belief (I quote Mark Crane) "that linguistic understanding could lead to deeper religious understanding". ${ }^{69} \mathrm{I}$ do not want to enter the debate on whether Bade's preface is meant to be an apology and might therefore be directed against Erasmus, who famously had called Bade a man who was more interested in earning money than in the litterae themselves. ${ }^{70}$ In my view, White rightly advocates a nuanced position: while there is no doubt that Bade's preface is part of the ongoing Ciceronian debate, "[i]t seems unlikely [...] that Badius intended the dedication as an attack on Erasmus. His remarks about Christian eloquence seem entirely in tune with the Erasmian position". ${ }^{71}$ More important for the purpose of this chapter is the fact that he made the claim in an edition of one of the champions of ancient rhetoric, Cicero. He thereby links the Ciceronian debate closely to its late antique predecessors and at the same time enhances Cicero's authority through the authority of

Dei negligenter'. ('How much more fitting is it that we, when interpreting God's eloquence ac-
cording to human intellect, show ourselves worthy of the task! For we are a certain instrument
of the Holy Ghost through which the variety of his voice and the diversity of his doctrine can be
perceived. Therefore let us be wakeful that we do not say anything mean, out of respect for the
following lawful judgment: 'Cursed anyone who fulfils God's works carelessly'." The final quote
is from Ier. 48:10. 68 Cf. ASD I-2, 1971, 637-639. See Del Giovane in this volume for the sixteenth-century debate and especially for Erasmus' take on Cicero's De officiis.

69 Cf. Crane 2012, 103.

70 Lebel 1988, 17 advocates the idea of the preface being an anti-Erasmian apologetic text, "une véritable profession de foi” (following a suggestion by Renouard 1908, vol. 1, 28). On Erasmus' (and other humanists') criticism of Bade's economical interest, see Diu 1997. In the Ciceronianus (ASD I-2, 672-673), Nosoponus says that he would rather admit Bade in the circle of Ciceronianists than Guillaume Budé, and that Bade would have been an even more successful stylist if he had dedicated more time to the studies and less to his personal economy (nisi curae domesticae reique parandae studium interrupissent ocium illius musis amicum). But as this judgment is pronounced by the Ciceronianus himself, i.e. by the figure that is ridiculed, it has to be taken cum grano salis.

71 White 2013, 57; cf. also Crane 2012, 109. 
Jerome, Augustine, and all the "six hundred others". While his preface excludes references to the political Cicero, which we have seen so prominently in the introductions by Maturanzio and Beroaldo, it adds a theological element to Cicero's oratorical testament. Bade's program could be summarized as follows: "I am interested in propagating Christian faith by propagating the universal qualities of Cicero, which are acknowledged by very different humanistic authorities; all of these authorities incorporate many ancient authorities for their claim that the Philippics are the best of Rome's best orator". Herewith, he sided with the commentators he published that studying Cicero is no mere matter of style, but also of content; and he shared their method of keeping alive important moments of the Ciceronian tradition that had already lasted for more than 1500 years in his time.

\section{Conclusion}

While commentaries have often been defined as media for negotiating power, Paul White has reminded us that they could also negotiate legacy. He thinks of Bade as defining and thereby codifying his own intellectual legacy which he wished to leave as a commentator and publisher. However, in his edition of Cicero's Philippics at least two other cultural legacies are at stake as well. On the one hand, the edition serves as a mediator for the intellectual heritage of Italian Quattrocento humanism in Northern Europe. On the other hand, the Italian commentators themselves read the Philippics as Cicero's legacy, his Spätwerk, and discuss his importance as an oratorical, political and moral authority. ${ }^{72}$ In order to do so, the reception of the Philippics in the commentaries is at the same 'reception of Cicero' and 'reception of the Ciceronian tradition', as it relates closely to early imperial, late antique and early humanistic moments of transforming Cicero into a cultural icon. For this reason, Bade's edition is a truly rich treasure that can exemplify early modern appropriation of Cicero's final years. ${ }^{73}$

72 Thus Bade's commentary (similarly to what Van der Velden in this volume postulates for the Epistula ad Octauianum) unites different strands of the Ciceronian tradition-the rhetorical, political and moral authority-into an iconic image of excellence and a major model for multi-layered imitation and emulation.

73 I thank the participants of the CCC workshop and especially my Leiden colleagues Bram van der Velden and Leanne Jansen for many valuable suggestions and corrections. I am grateful to Cecilia Mussini for having sent me her unpublished Ph.D. thesis. Laura Napran kindly corrected my English. The sharp eyes of Ermanno Malaspina saved me from several infelicities. Research 
for this chapter has been made possible by a VIDI grant of the Dutch Research Council (NWO), funding no. 276-30-013. 
